\title{
Analisis Nutrisi Rumput Alam (Mexicana grass) dan Rumput Raja (King grass) Sebagai Pakan Ternak di Kelompok Tani Nekmese Kecamatan Insana Barat pada Musim Kemarau
}

Genosela Virginia Tas'au dan Oktovianus R. Nahak T. $\mathrm{B}^{\mathrm{b}}$

${ }^{a}$ Fakultas Pertanian, Universitas Timor, Kefamenanu, TTU - NTT, 85613, Indonesia.

${ }^{\mathrm{b}}$ Fakultas Pertanian, Universitas Timor, Kefamenanu, TTU - NTT, 85613, Indonesia.

\section{Article Info}

\section{Article history:}

Received 10 Januari 2016

Received in revised form 20 Februari 2016 Accepted 13 Maret 2016

\section{Keywords:}

Rumput Alam

Rumput Raja

Protein Kasar

Bahan Kering

Bahan Organik

\section{Pendahuluan}

Peningkatan produksi ternak tidak terlepas dari pengadaan pakan, karena pakan merupakan kebutuhan utama untuk kelangsungan hidup, produksi dan reproduksi. Pakan utama bagi ternak ruminansia adalah hijauan baik rumput maupun legum sehingga penyediaan pakan hijauan baik kualitas maupun kuantitas merupakan hal penting yang perlu diperhatikan dalam usaha peternakan.

Kenyataannya di NTT menunjukkan bahwa pada musim hujan yang lamanya tiga sampai empat bulan per tahun, ketersediaan hijauan pakan (rumput alam) berada dalam jumlah cukup bahkan berlebihan sebaliknya pada musim kemarau yang lamanya delapan sampai sembilan bulan ketersediaan rumput alam masih cukup tetapi telah menurun kualitasnya (Hau, 2005).

Pola penggemukan sapi Bali Jantan di tingkat peternak saat ini sudah banyak dilakukan, salah satunya adalah penggemukan sapi Bali Jantan di kelompok tani "Nekmese, Kecamatan Insana Barat". Pada awalnya usaha in hanya bersifat sampingan tapi dengan berkembangnya permintaan ternak untuk diekspor maka menjadi satu peluang bagi peternak untuk meningkatkan pendapatan. Pola penggemukan ternak sapi yang dilakukan oleh kelompok tani Nekmese adalah pola penggemukan dengan memanfaatkan hijauan jenis rumput baik rumput alam (Mexicana grass) maupun rumput raja (King grass) sebagai bahan pakan utama.

Kualitas rumput alam merupakan sumber pakan utama ternak ruminansia Gunawan (1998) lebih lanjut menjelaskan bahwa rumput atau hijauan lainnya memegang peranan penting sebagai pakan utama ternak ruminansia di Indonesia. Hal ini disebabkan karena rumino-retikulum ternak ruminansia terdapat mikroba yang membantu proses pencernaan serat kasar sebagai bahan makanan yang tidak dapat digunakan oleh jenis ternak lain. Umumnya bahan pakan dasar yang ada seperti rumput alam memiliki kecernaan yang relatif rendah. Rendahnya kualitas bahan pakan tentunya dapat berpengaruh terhadap nilai kecernaan bahan pakan dan pada akhirnya berdampak pada rendahnya pertambahan berat badan dan ukuran linear tubuh ternak.

Hal ini berbeda dengan rumput raja yang memiliki kualitas nutrisi dan kecernaan yang lebih baik dibanding rumput alam. Rumput ini merupakan persilangan antara rumput berjenis unggul. Rumput raja dapat hidup di dataran rendah hingga dataran tinggi. Rumput raja yang ditanam di dataran rendah memilki ruas daun yang lebih besar dari pada yang ditanam di dataran tinggi. Rumput raja memiliki produktivitas yang cukup tinggi dengan tingginya dapat mencapai 3-4 m

Pada daerah tropis kering, pada saat rumput mulai tua, kandungan rumput mulai berkurang maka selera makan mulai turun sehingga konsumsi rumput berkurang karena menurunya daya cerna pakan. Daya cerna rumput raja dapat mencapai $70 \%$ pada pertumbuhannya dan akan menurun hingga $40-50 \%$ sesuai dengan bertambahnya umur tanaman, sehingga menyebabkan turunnya berat hidup ternak. Hijauan makanan ternak di daerah tropis lebih cepat berbunga dan cepat menjadi tua yang diiringi dengan menurunnya kadar protein dan meningkatnya serat kasar.

Penelitian ini bertujuan untuk menganalisis kandungan nutrisi rumput alam dan rumput raja yang digunakan sebagai pakan ternak sapi pada kelompok Tani Nekmese, Kecamatan Insana Barat.

\section{Metode}

\subsection{Waktu dan Tempat}

Penelitian ini dilaksanakan di Kelompok Tani Nekmese, Kecamatan Insana Barat, Kabupaten Timor Tengah Utara, selama 5 minggu terhitung tanggal 26 Juli sampai 31 Agustus 2015, sedangkan analisis laboratorium dilakukan di Laboratorium Kimia Pakan, Fakultas Peternakan, Universitas Nusa Cendana Kupang, dimulai dari tanggal 16-17 September 2015.
2.2 Variabel

Penentuan kadar protein bahan dilakukan melalui tahap-tahap yakni melakukan penimbangan bahan sampel yang telah dikeringkan dan dihaluskan sebanyak 5 gr. Sampel dimasukan ke dalam labu destruksi kemudian ditambahkan \pm 6 gram katalis serta $25 \mathrm{ml} \mathrm{H}_{2} \mathrm{SO}_{4}$ pekat. Campuran dipanaskan awalnya dengan api kecil di atas nyala pembakaran di dalam lemari asap. Apabila tidak berbuih lagi maka nyala api baru diperbesar. Sampel terus didestruksi sampai larutan jernih dan berwarna hijau. Dilakukan pendinginan pada labu destruksi dan larutan dimasukan ke dalam labu penyuling kemudian dilakukan pengenceran dengan $300 \mathrm{ml}$ air. Larutan dijadikan basa dengan

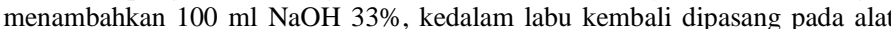
penyuling. Hasil penyulingan $\mathrm{NH}_{3}$ dan air ditangkap dalam suatu elenmeyer yang telah diberi $\mathrm{H}_{2} \mathrm{SO}_{4}$ penyulingan terus dilakukan sampai semua $\mathrm{N}$ tertangkap $\mathrm{H}_{2} \mathrm{SO}_{4}$. Labu elenmeyer bersi sulingan diambil dan kelebihan $\mathrm{H}_{2} \mathrm{SO}_{4}$ dititrasi dengan larutan $\mathrm{NaOH}$. Perubahan warna dari biru kehijauan menandakan titik akhir kemudian dibandingkan hasil titrasi blanko. Rumus yang digunakan:

$$
\text { Kadar Protein Kasar }=\frac{(Y-Z) \times \text { TiterNaoH } \times 0,01 \times, 25}{X} 100 \%
$$

$$
\begin{array}{lll}
\mathrm{Y} & : & \text { Hasil titrasi blanko }(\mathrm{ml}) \\
\mathrm{Z} & : & \text { NaOH yang dibutuhkan untuk titrasi }(\mathrm{ml}) \\
\mathrm{X} & : & \text { Banyaknya sampel yang digunakan untuk analisis (gr) }
\end{array}
$$

Adapun prosedur analisis untuk memperoleh kandungan bahan organik yakni 1) Digestion, merupakan proses dimana semua protein yang terkandung di dalam sampel didestruksi (dipecah), sehingga ikatan peptida terpecah sampai terbentuk ammonia dalam bentuk ion ammonium $\left(\mathrm{NH}_{4}+\right)$; 2) Destilasi, proses ini berfungsi untuk mendapatkan gas ammonia $\left(\mathrm{NH}_{3}\right)$. Proses destilasi dilakukan dengan cara menaruh hasil destruksi kadestilator. Pada proses ini dilakukan dengan penambahan asam hidroksida $(\mathrm{NHOH})$ sehingga hasil dari reaksi dari $\mathrm{NHOH}$ dengan ammonium sulfat menghasilkan gas amonia; 3) Titrasi, langkah terakir dalam proses analisis protein adalah titrasi. Dengan pengembangan teknologi saat ini proses titrasi dapat dilakukan dengan metode potensiometri. Metode ini dilakukan dengan menggunakan elektrode $\mathrm{pH}$. Larutan yang telah mengandung ion borat dengan adanya klorida. Maka berapa jumlah asam klorida yang digunakan akan berfungsi sebagai data untuk mengkalkulasikan hasil protein sampel tersebut.

Pengukuran bahan kering dilakukan analisa laboratorium menggunakan oven dengan suhu $105^{\circ} \mathrm{C}$. Adapun prosedur analisanya yakni 1) Diambil sampel sebanyak 1,5 gr (A) kemudian dioven dengan suhu $65^{\circ} \mathrm{C}$ (Kering Udara) selama 2 hari. Kemudian ditimbang (B); 2) Cawan porselin yang sudah bersih dikeringkan dengan oven pengering pada suhu $105^{\circ} \mathrm{C}$ selama 1 jam (tutup dilepas); 3) Cawan porselin (tutup dilepas) didinginkan dalam desikator selama 1 jam, kemudian ditimbang dalam keadaan tertutup (X) gram; 4) diambil sebanyak sampel 1,5 gram (Y) dan dimasukan ke dalam cawan dan Dioven selama 8-12 jam pada suhu $105^{\circ} \mathrm{C}$. Selanjutnya didinginkan dalam desikator selama 1 jam. Setelah dingin kemudian ditimbang sebnyak 3 kali tiap jam sampai beratnya konstan (Z). Kalkulasi Berat Kering:

$$
B K \%=\frac{B}{A} X \frac{Z-X}{Y} X 100 \%
$$

Keterangan :

a : Berat sampel awal

b : Berat sampel kering oven $65^{\circ} \mathrm{C}$

$\mathrm{X}$ : Cawan kosong

$\mathrm{Y}$ : Berat sampel

$\mathrm{Z}$ : Berat cawan + sampel $105^{\circ} \mathrm{C}$ 


\subsection{Prosedur Penelitian}

Penelitian dilakukan melalui prosedur-prosedur yakni 1) Mengambil sampel pakan berupa rumput alam (Mexicana gress) dan rumput raja (King grass) pada kebun masyarakat; 2) Penimbangan berat pakan sebagai sampel; 3 ) Sampel dijemur sampai kering; 4) Sampel dihaluskan menggunakan alat bantu blender atau mol hijauan pakan; 5) Setelah sampel diambil, dibawa ke laboratorium untuk dianalisis.

\subsection{Analisis Data}

Data yang diperoleh dikumpulkan kemudian ditabulasikan dengan menggunakan analisis Deskriptif, Standar Deviasi dan Koevisien Variasi sesuai petunjuk Steel dan Torrie (1995).

\section{Hasil dan Pembahasan}

3.1 Nilai Nutrisi Rumput Alam

Rumput alam merupakan sumber serat potensial bagi ternak. Ketersediaan rumput yang berkualitas merupakan hal penting mengingat bahwa rumput alam merupakan pakan bagi ternak yang dibutuhkan dalam jumlah besar pada penyusunan ransum. Nilai nutrisi rumput alam dapat dilihat pada Tabel 1 .

Tabel 1. Nilai Nutrisi Rumput Alam pada Waktu Pengambilan Berbeda (\%)

\begin{tabular}{cccc}
\hline Umur Rumput & Protein Kasar & Bahan Kering & Bahan Organik \\
\hline 1 Minggu & 4,05 & 94,95 & 90,47 \\
2 Minggu & 4,45 & 94,18 & 89,51 \\
3 Minggu & 5,91 & 94,98 & 88,52 \\
4 Minggu & 3,41 & 95,03 & 88,88 \\
5 Minggu & 5,69 & 95,38 & 90,00 \\
\hline Jumlah & 23,51 & 474,52 & 447,38 \\
\hline Rataan & 4,70 & 94,90 & 89,48 \\
\hline
\end{tabular}

Hasil penelitian menunjukkan bahwa rata-rata nilai kandungan protein rumput alam sebesar $4,70 \%$. Selama pengambilan sampel dilakukan nampak bahwa nilai protein rumput alam sangat bervariasi. Perbedaan nilai nutrisi protein kasar rumput alam dapat disebabkan karena faktor usia tanaman, selain itu dapat disebabkan karena perubahan iklim yang terjadi seiring penelitian berlangsung (Darmono, 1993).

Bamualim et al. (1990), mengatakan bahwa kualitas rumput alam di daerah tropis NTT, khususnya di pulau Timor dan Sumba yaitu kisaran protein kasarnya $3-8 \%$. Keadaan ini berada pada ambang minimal kebutuhan protein kasar untuk ternak ruminansia sebesar $8 \%$ menurut Soesetyo (1974). Hasil perhitungan standar deviasi kandungan protein kasar 1,07 sedangkan nilai koefisien variasi sebesar $22,75 \%$, dapat dikatakan bahwa variasi nilai protein kasar rumput cukup tinggi, hal ini disebabkan karena fluktuasi nilai nutrisi protein kasar rumput alam.

Pada nilai bahan organik rumput alam rata-rata sebesar $89,48 \%$, hal ini tergolong cukup tinggi. Tingginya bahan organik dapat menyebabkan tersedianya nutrien yang cukup pada bahan organik sehingga variasi nutrien akan semakin tinggi. Hasil perhitungan standar deviasi bahan organik menunjukkan nilai sebesar 0,79 dan nilai koefisien variasi sebesar $0,88 \%$. Hal ini menunjukkan bahwa keragaman nilai bahan organik pada setiap sampel yang diambil relatif sama (homogen) dengan kata lain bahwa nilai homogenitas bahan organik relatif sama.

Perhitungan bahan kering rumput alam menunjukkan nilai rataan sebesar 94,90, kondisi ini tergolong sangat tinggi. Kandungan bahan kering yang tinggi dapat disebabkan karena rendahnya kadar air pada bahan rumput alam. Hasil perhitungan standar deviasi bahan kering menunjukan nilai sebesar 0,44 dan koefisien variasi sebesar $0,46 \%$, dapat dikatakan nilai bahan kering memiliki tingkat homogenitas yang rendah atau nilai bahan kering sampel rumput alam yang diambil relatif sama.

\subsection{Nilai Nutrisi Rumput Raja}

Rumput raja merupakan salah satu jenis rumput unggulan dan saat ini sudah banyak digunakan sebagai pakan ternak ruminansia. Rumput raja dikenal memiliki nilai nutrisi yang cukup baik selain itu rumput raja juga memiliki nilai palatabilitas yang tinggi. Hasil perhitungan nilai nutrisi rumput raja dapat dilihat pada Tabel 2 .

\begin{tabular}{cccc}
\multicolumn{4}{c}{ Tabel 2. Nilai Nutrisi Rumput Raja pada Waktu Pengambilan Berbeda $(\%)$} \\
\hline Umur Rumput & Protein Kasar & Bahan Kering & Bahan Organik \\
\hline 1 Minggu & 12,43 & 95,48 & 83,30 \\
2 Minggu & 11,61 & 95,00 & 87,86 \\
3 Minggu & 10,62 & 94,76 & 89,60 \\
4 Minggu & 9,76 & 95,33 & 83,75 \\
5 Minggu & 9,15 & 94,65 & 87,33 \\
\hline Jumlah & 53,57 & 475,22 & 431,84 \\
\hline Rataan & 10,71 & 95,04 & 86,37 \\
\hline
\end{tabular}

Hasil Perhitungan menunjukkan bahwa nilai protein kasar rumput raja adalah sebesar $10,71 \%$. Hal ini menunjukan bahwa kandungan protein kasar rumput raja lebih tinggi dibandingkan rumput alam (4,70\%). Hasil perhitungan standar deviasi dan koefisien variasi protein kasar rumput raja adalah masingmasing sebesar 1,3 dan $12,44 \%$, hal ini menunjukkan bahwa nilai variasi nilai protein kasar tergolong cukup tinggi sehingga dapat dikatakan bahwa nilai homogenitas protein kasar rumput gajah tergolong rendah (bervariasi).

Hasil perhitungan bahan organik sebesar 86,37 dimana bahan organik tergolong tinggi mengingat kandungan air pada bahan diperkirakan sudah mengalami penurunan. Nilai standar deviasi dan koefisien variasi pada bahan organik masing-masing sebesar 2,73 dan 3,16\%, hasil ini masih dapat dikatakan rendah sehingga dapat diartikan bahwa homogenitas nilai bahan organik pada rumput raja relatif sama.

Pada perhitungan nilai rataan bahan kering rumput raja sebesar 95,04\%. Hal ini menunjukkan bahwa nilai bahan kering rumput raja tergolong tinggi. Pada perhitungan standar deviasi dan koefisien variasi bahan kering masingmasing sebesar 0,35 dan $0,30 \%$, hal ini dapat dikatakan bahwa nilai homogenitas bahan kering relatif sama pada semua sampel rumput raja yang diambil.

\section{Simpulan}

Berdasarkan hasil penelitian dan pembahasan disimpulkan bahwa nilai nutrisi pada rumput alam memiliki protein kasar dengan rata-rata $4,70 \%$, bahan kering $94,90 \%$, dan bahan organik $89,48 \%$. Bahan kering memiliki tingkat homogenitas yang tinggi atau dapat dikatakan bahwan nilai sampel rumput yang diambil relatif sama. Sedangkan pada rumput raja memiliki nilai nutrisi dengan rata-rata protein kasar $10,71 \%$. Hal ini menunjukkan bahwa kandungan protein kasar rumput raja lebih tinggi dibandingkan rumput Alam $(4,70 \%)$. Nilai bahan kering $95,04 \%$ dan bahan organik memiliki nilai nutrisi sebanyak $86,37 \%$.

\section{Pustaka}

Babualim, A Saleh dan W. R. Babualim 1990. Produksi dan kualitas hijauan. Darmono.1999. Tatalaksana Usaha Sapi Keremau. Kanisius. Yogyakarta.

Gunawan, S. 2008. Bibit Sapi Potong. Pusat Pengembangan Pendidik dan Penataran Guru (PPPPG) Pertanian Cianjur. Jawa Barat.

Hau, Erich.2005. Wind Turbines : Fundamentals, Technologies, Aplication, Economics. Springer. Berlin.

Soesetyo, S. 1974. Beberapa Aspek Teknis dalam Rangka Produksi Hijauan Makanan Ternak. Fapet IPB Bogor.

Steel, R.G.D. dan Torrie, J.H. 1995. Prinsip dan prosedur Statistika: Suatu Pendekatan Biometrik. Jakarta: Gramedia. 